\title{
STRATEGI PENGEMBANGAN USAHATANI BAWANG MERAH DI DESA SUNGAI GERINGGING KECAMATAN KAMPAR KIRI KABUPATEN KAMPAR PROVINSI RIAU
}

\author{
Development Strategy on Shallot Farming in Sungai Geringging Village \\ Kampar Kiri District, Kampar Regency, Riau Province
}

\author{
Sri Ayu Kurniati \\ Fakultas Pertanian Universitas Islam Riau \\ Jl. Kaharuddin Nasution No. 113 Pekanbaru 28284 \\ Email: sriayukurniati@agr.uir.ac.id \\ [Diterima: Februari 2019; Disetujui: Maret 2019]
}

\begin{abstract}
ABSTRAK
Shallot plant has a good prospect to be developed if farmers have a desirability and ability to cultivate it. The purpose of this study was to identify the internal and external environment and to formulate a shallot farming development strategy. The research used a survey method located in Sungai Geringging Village, Kampar Kiri District, Kampar Regency and was selected 40 farmers as respondents. The data were analyzed using IFE, EFE and the SWOT. The results of external opportunities showed that Kampar Regency is a center for shallot cultivation, while fluctuations in the selling price of production were considered a threat factor. The use of the improved yielding seed was a strength, and a weakness was the transportation facility. The IE matrix indicated that the shallot farming is in cell III, so that it can carry out market penetration strategies and product development. The SWOT matrix showed that farming could carry out the WO (Weaknesses-Opportunities) strategy, namely with increasing optimally business capabilities related to capital loans, using applied technology through training. It requires the role of the government in accessing modern markets and increasing the ability of farmers to do business through information technology facilities and regional autonomy policies.
\end{abstract}

Keywords: Shallot, Strategy, Business Development, External, Internal

\begin{abstract}
ABSTRAK
Tanaman bawang merah memiliki prospek untuk di kembangkan jika petani memiliki kemauan dan kemampuan dalam pengusahaannya. Tujuan penelitian ini adalah untuk mengidentifikasi lingkungan internal dan eksternal serta merumuskan strategi pengembangan usahatani bawang merah. Penelitian menggunakan merode survei di Desa Sungai Geringging Kecamatan Kampar Kiri Kabupaten Kampar, dengan junlah responden sebanyak 40 orang petani. Analisis data yang digunakan adalah analisis IFE EFE dan analisis SWOT. Hasil penelitian pada peluang eksternal menyatakan bahwa Kabupaten Kampar merupakan sentra penanaman bawang merah sementara fluktuasi harga jual produksi dianggap sebagai ancaman. Penggunaan bibit unggul merupakan kekuatan dan kelemahannya adalah sarana transportasi yang masih sederhana. Matriks IE menyatakan usahatani bawang merah berada pada sel III, sehingga dapat menjalankan strategi penetrasi pasar dan pengembangan produk dan matriks SWOT menunjukkan bahwa usahatani dapat menjalankan strategi WO (Weaknesses-Opportunities) yaitu meningkatkan kemampuan usaha secara optimal terkait pinjaman modal, menguasai teknologi terapan melalui pembinaan pelatihan. Hal ini diperlukan peran pemerintah dalam akses pasar modern dan meningkatkan kemampuan berusahatani melalui sarana teknologi informasi dan kebijakan otonomi daerah.
\end{abstract}

Kata Kunci: Bawang Merah, Strategi, Pengembangan Usaha, Eksternal Internal.

\section{PENDAHULUAN}

Pembangunan pertanian sub sektor tanaman pangan khususnya hortikultura dapat tumbuh dengan cepat dan secara fungsional dapat berperan dalam penyediaan bahan baku industri, peningkatan pendapatan petani, menciptakan lapangan kerja, serta peningkatan 
penerimaan devisa melalui ekspor hasil tanaman hortikultura. Bawang merah (Allium ascalonicum $L$ ) adalah salah satu umbi lapis yang banyak tumbuh hampir di semua dataran rendah, bernilai ekonomi tinggi, umumnya diusahakan oleh petani secara komersial yang sebagian besar atau seluruh hasil produksinya ditujukan untuk memenuhi permintaan pasar. Tingginya tingkat konsumsi masyarakat menjadikan komoditas bawang merah ini menguntungkan jika diusahakan.

Potensi pengembangan bawang merah di Kabupaten Kampar difokuskan di Desa Sungai Geringging karena ketersediaan lahan kering yang luas dan subur untuk budidaya bawang merah yakni mencapai 40.684 hektar. Jumlah produksi dan tingkat kebutuhan nasional merupakan faktor determinan yang cukup kuat mempengaruhi keputusan untuk mendorong pengembangan dan peningkatan produksi di tingkat lokal. Petani bawang merah dalam menjalankan usahataninya, tidak terlepas dari pengaruh dan permasalahan lingkungan, baik secara internal maupun eksternal. Permasalahan internal umumnya adalah kurangnya kemampuan penerapan teknologi oleh petani, sempitnya penguasaan lahan, lemahnya permodalan, dan terbatasnya ketersediaan input, sedangkan secara eksternal permasalahan yang biasa terjadi yaitu iklim yang tidak menentu, serangan organisme pengganggu tanaman, dan fluktuasi harga bawang merah. Ditinjau dari aspek pemasaran, proyeksi kebutuhan bawang merah sangat menguntungkan, tetapi harus diimbangi dengan penggunaan input yang optimal.

Petani bawang merah di Kabupaten Kampar pada umumnya adalah petani swadaya yang mengusahakan seluruh sarana dan kegiatan produksi secara mandiri. Petani memiliki ketertarikan untuk mengusahakan bawang merah didasari oleh ketersediaan lahan yang cukup, proses penanaman dilakukan bersama-sama dengan petani lain, harapan keuntungan yang besar, meskipun terdapat beberapa petani yang akhirnya beralih ke tanaman lain. Pada kenyataannya dalam menyikapi beberapa permasalahan usahatani bawang merah petani dihadapkan pada dilema apakah tetap mengusahakan atau beralih pada komoditi lain mengingat harga input dan harga jual yang selalu berfluktuasi. Berdasarkan hal tersebut maka tujuan penelitian ini adalah mengidentifikasi lingkungan internal dan eksternal serta merumuskan strategi pengembangan usahatani bawang merah di Desa Sungai Geringging Kecamatan Kampar Kiri Kabupaten Kampar Propinsi Riau.

\section{METODE PENELITIAN}

Penelitian ini menggunakan metode survei di Desa Sungai Geringging Kecamatan Kampar Kiri Kabupaten Kampar karena merupakan daerah awal pengembangan budidaya bawang merah di Propinsi Riau dengan penentuan responden secara sensus kepada 40 petani. Jenis data terdiri dari data primer yang meliputi identitas petani (umur, lama pendidikan, jumlah anggota keluarga, pengalaman berusaha), luas lahan, penggunaan sarana produksi, jumlah produksi dan jumlah tenaga kerja, serta sekunder yaitu data yang berasal dari dinas dan instansi terkait dan dipublikasikan kepada masyarakat pengguna. Data skunder meliputi gambaran umum daerah, penduduk, luas areal dan jumlah produksi bawang merah, dan data pendukung lain yang diperoleh dari Kantor Kecamatan, BPS, Dinas Tanaman Pangan dan Hortikultura.

\section{ANALISIS DATA}

\section{Identifikasi Faktor Eksternal dan Internal}

Matriks EFE berisi strategi usaha yang secara efektif mengambil keuntungan dari peluang dengan meminimalkan efek yang muncul dari ancaman luar meliputi ekonomi, sosial, budaya, demografi, lingkungan, politik, pemerintah, hukum, teknologi, dan kompetitif, seperti terlihat Tabel 1.

Sementara matriks IFE merupakan strategi usaha yang secara efektif memanfaatkan kekuatan yang dimiliki untuk meminimalkan kelemahan, meliputi komponen manajemen, pemasaran, keuangan, produksi, peneitian dan pengembangan, serta sistem informasi manajemen, seperti terlihat pada Tabel 2.

Matriks internal eksternal (IE) memposisikan perusahaan dalam sembilan tampilan sel pada sebuah diagran skematis (David, 2009) yang didasarkan pada dua dimensi kunci yaitu total rata-rata tertimbang IFE pada sumbu $\mathrm{x}$ dan total rata-rata tertimbang EFE pada sumbu y dimana terdapat total rata-rata tertimbang dari $1,0-1,99$ dianggap rendah, nilai $2,0-2,99$ adalah menengah, dan 3,0 - 4,0 adalah tinggi. 
Tabel 1. Faktor Eksternal Usahatani Bawang Merah di Desa Sungai Geringging

\begin{tabular}{|c|c|c|}
\hline Faktor Eksternal & Peluang & Ancaman \\
\hline Ekonomi & $\begin{array}{l}\text { Adanya permintaan pasar yang } \\
\text { potensial }\end{array}$ & Harga jual produksi berfluktuasi \\
\hline \multirow{2}{*}{$\begin{array}{l}\text { Sosial, budaya, demografi, dan } \\
\text { lingkungan }\end{array}$} & Peningkatan jumlah penduduk & \multirow{2}{*}{$\begin{array}{l}\text { Jumlah petani tidak banyak } \\
\text { Serangan hama dan penyakit } \\
\text { Perubahan iklim dan cuaca }\end{array}$} \\
\hline & $\begin{array}{l}\text { Subsistem agribisnis mendominasi } \\
\text { lapangan pekerjaan }\end{array}$ & \\
\hline \multirow[t]{2}{*}{ Politik, hukum, dan pemerintah } & $\begin{array}{l}\text { Adanya pembinaan dan pelatihan } \\
\text { dari penyuluh }\end{array}$ & \\
\hline & $\begin{array}{l}\text { Otonomi daerah mendorong } \\
\text { kegiatan agribisnis lebih kompetitif }\end{array}$ & \\
\hline \multirow[t]{2}{*}{ Teknologi } & $\begin{array}{l}\text { Sarana dan prasarana pertanian } \\
\text { tersedia }\end{array}$ & \\
\hline & $\begin{array}{ll}\text { Berkembangnya } & \text { teknologi } \\
\text { informasi pertanian } & \\
\end{array}$ & \\
\hline Kompetitif & $\begin{array}{l}\text { Kabupaten Kampar sebagai sentra } \\
\text { penanaman bawang merah }\end{array}$ & \\
\hline
\end{tabular}

Tabel 2. Faktor Internal Usahatani Bawang Merah di Desa Sungai Geringging

\begin{tabular}{|c|c|c|}
\hline Faktor Internal & Kekuatan & Kelemahan \\
\hline \multirow[t]{4}{*}{ Manajemen } & $\begin{array}{l}\text { Petani berpengalaman dalam } \\
\text { usahatani }\end{array}$ & \multirow[t]{4}{*}{ Usahatani masih berskala kecil } \\
\hline & $\begin{array}{l}\text { Banyak menggunakan tenaga kerja } \\
\text { dalam keluarga }\end{array}$ & \\
\hline & Tergabung dalam kelompok tani & \\
\hline & Manajemen usahatani cukup baik & \\
\hline Pemasaran & & $\begin{array}{ll}\text { Sarana } & \text { transportasi } \\
\text { sederhana } & \\
\end{array}$ \\
\hline \multirow[t]{4}{*}{ Produksi } & Penggunaan bibit unggul & \multirow[t]{4}{*}{ Fasilitas kerja manual } \\
\hline & Pupuk cukup tersedia & \\
\hline & Sistem pengairan yang baik & \\
\hline & $\begin{array}{l}\text { Teknik budidaya } \\
\text { rekomendasi }\end{array}$ & \\
\hline
\end{tabular}

Matriks IE membagi tida daerah utama yang memiliki implikasi strategi yang berbedabeda. Pertama, usaha yang masuk dalam sel I, II, atau IV digambarkan sebagai tumbuh dan kembang sehingga strategi yang sesuai adalah strategi intensif (penetrasi pasar, pengembangan pasar dan pengembangan produk) atau integratif (integrasi kebelakang, integrasi kedepan, dan integrasi horizontal). Kedua, usaha yang masuk dalam sel III, V, atau VII dapat dikelola dengan strategi intensif (penetrasi pasar dan pengembangan produk). Ketiga, bagi usaha pada sel VI, VIII, dan IX maka strategi yang digunakan adalah strategi divestasi, seperti gambar berikut:

Total Nilai IFE yang diberi bobot

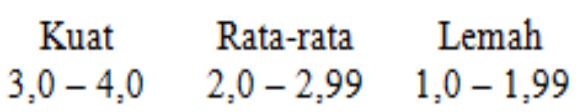

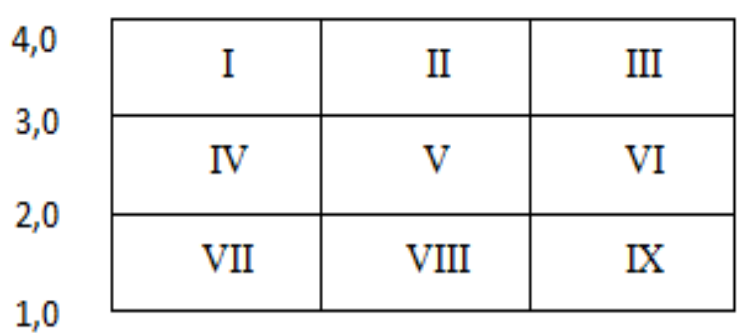

Gambar 1. Matriks Internal Eksternal (IE) 


\section{Strategi Pengembangan Usaha}

Matriks SWOT merupakan tahap pencocokan faktor eksternal dan internal kunci yang membutuhkan penilaian yang baik dan umumnya bersifat subyektif karena menganggap tidak ada pencocokan yang terbaik. Terdapat 4 strategi, yakni Strategi SO menggunakan kekuatan internal perusahaan untuk memanfaatkan peluang eksternal, strategi WO bertujuan untuk memperbaiki kelemahan internal dengan memanfaatkan peluang eksternal. Strategi ST menggunakan kekuatan internal untuk menghindari atau mengurangi pengaruh dari ancaman eksternal. Strategi WT adalah pengurangan kelemahan internal dan menghindari ancaman eksternal. Untuk lebih jelas terlihat pada tabel berikut:

Tabel 3. Matriks SWOT

\begin{tabular}{l} 
Faktor eksternal \\
\hline \multicolumn{1}{c}{ Peluang (O) } \\
Ancaman (W)
\end{tabular}

1. Adanya permintaan pasar yang potensial Permintaan pasar yang diharapkan tidak saja secara regional namun juga nasional bahkan internasional. Tingginya jumlah permintaan akan menjadi pendorong bagi peningkatan jumlah penawaran atas produksi bawang merah yang pada akhirnya peluang ekonomi ini akan dapat meningkatkan keuntungan dan pendapatan petani

2. Peningkatan jumlah penduduk

Jumlah penduduk yang bertambah berdampak pada peningkatan jumlah kebutuhan pangan. Secara sosial, budaya, demografi, dan lingkungan, kondisi ini merupakan peluang bagi keberlangsungan usahatani bawang merah

3. Subsistem agribisis mendominasi lapangan pekerjaan

Pengembangan 5 subsistem agribisnis dapat menjadi peluang bagi terbukanya lapangan pekerjaan. Petani dapat memilih salah satu subsistem (penyediaan sarana produksi, usahatani, agroindustri, pemasaran, dan penunjang) atau mengelola kelima subsistem tersebut.

4. Adanya pembinaan dan pelatihan dari penyuluh

Penyuluh sangat berperan dalam membantu petani melakukan usahataninya. Pembinaan dan pelatihan dari penyuluh merupakan peluang bagi petani untuk
Kekuatan (S) Kelemahan (W)

Strategi SO Strategi WO

Strategi SW Strategi WT

mengembangkan kemampuan diri dalam meningkatkan hasil produksi

5. Otonomi daerah mendorong kegiatan agribisnis lebih kompetitif

Diberlakukannya otonomi daerah maka pemerintah memberikan kebebasan bagi maasyarakat untuk melakukan kegiatan usaha agribisnis sesuai dengan ketentuan yang berlaku. Selain meningkatkan pendapatan dan kesejahteraan petani, namun juga peluang untuk berperan aktif meningkatkan pendapatan daerah

6. Sarana dan prasarana pertanian tersedia

Penggunaan sarana dan prasarana pertanian di daerah penelitian cukup tersedia meskipun masih sederhana dan tergolong semi teknis. Penerapan teknologi dapat menjadi peluang bagi petani untuk meningkatkan kemampuan dalam penggunaan fasilitas produksi yang lebih modern

7. Berkembangnya teknologi informasi pertanian

Kemajuan teknologi ditandai dengan penggunaan telepon seluler oleh petani untuk berkomunikasi dan berdiskusi dengan penyuluh mengenai kendala dan solusi dalam usahatani. Sehingga peluang untuk menerima dan mengembangkan teknologi dalam usahatani sangatlah terbuka, salah satunya melalui peran petani dalam kelompok tani

8. Kabupaten Kampar sebagai sentra penanaman bawang merah.

Telah diketahui lama bahwa Kabupaten Kampar merupakan daerah yang lebih dominan melakukan usahatani padi sawah dan tanaman perkebunan seperti karet. 
Namun pada tahun 2013 dilakukan penanaman bawang merah dengan produktivitas sebesar 4 ton/ha. Hal ini merupakan peluang sekaligus menjadi keunggulan kompetitif bila dibandingkan dengan daerah lain di Propinsi Riau.

\section{Ancaman}

1. Harga jual produksi berfluktuasi

Petani tidak memiliki kemampuan untuk menentukan harga produk. Penentuan harga yang tidak menguntungkan menjadi ancaman bagi peningkatan keuntungan dan pendapatan petani. Fluktuasi harga bawang merah tidak semata-mata disebabkan oleh kendala dalam berusahatani tetapi lebih didominasi oleh keadaan/moment tertentu, misal mendekati perayaan hari besar agama. Jika harga terlalu rendah biasanya petani menahan dulu hasil produksinya dengan cara menjemur dan disimpan, dan akan dijual kembali saat harga kembali normal atau penjualan menguntungkan

2. Jumlah petani bawang merah tidak banyak Kuantitas petani yang tidak terlalu banyak (di lokasi penelitian $<40$ orang) menimbulkan kekhawatiran bagi keberlanjutan usahatani mengingat bawang merah dibutuhkan untuk pangan masyarakat. Kondisi ini akan menjadi ancaman bagi ketersediaan bawang merah dimasa datang dan akan tergantung pada produksi dari daerah lain

3. Adanya serangan hama dan penyakit

Hama dan penyakit merupakan faktor alam yang muncul secara alami, diantaranya yaitu jenis fusarium. Cara-cara dan fasilitas yang digunakan umumnya sederhana. Serangan hama dan penyakit dapat mengancam pertumbuhan tanaman dan jumlah produksi yang dihasilkan. Untuk mencegah berkembangnya hama tersebut petani biasanya rutin menyiram bawang merah mereka untuk mencegah terjadinya pengembunan pada batang dan daun

4. Perubahan iklim dan cuaca

Berada di wilayah tropis memberikan keuntungan dan kerugian bagi kelangsungan usahatani. Perubahan cuaca lebih cepat terjadi sementara tanaman kurang tanggap terhadap perubahan tersebut. Kerusakan yang dialami menjadi ancaman bagi kondisi sosial budaya petani dan lingkungan sekitar.

Tabel 4. Matriks EFE (External Factor Evaluation)

\begin{tabular}{|c|c|c|c|}
\hline Faktor Strategis Eksternal & Bobot & Rating & Nilai Tertimbang \\
\hline \multicolumn{4}{|l|}{ Peluang (Opportunities) } \\
\hline $\begin{array}{ll}\text { 1. Kabupaten Kampar sebagai sentra penanaman bawang } \\
\text { merah }\end{array}$ & 0,100 & 3,825 & 0,381 \\
\hline 2. Peningkatan jumlah penduduk & 0,095 & 3,650 & 0,347 \\
\hline 3. Adanya permintaan pasar yang potensial & 0.092 & 3,525 & 0,324 \\
\hline 4. Sistem agribisnis mendominasi lapangan pekerjaan & 0,079 & 3,050 & 0,242 \\
\hline 5. Sarana dan prasarana pertanian tersedia & 0,077 & 2,975 & 0,230 \\
\hline 6. Berkembangnya teknologi informasi pertanian & 0,085 & 3,275 & 0,279 \\
\hline 7. Adanya pembinaan dan pelatihan dari penyuluh & 0,089 & 3,425 & 0,305 \\
\hline $\begin{array}{l}\text { 8. Otonomi daerah mendorong kegiatan agribisnis lebih } \\
\text { kompetitif }\end{array}$ & 0,048 & 1,850 & 0,089 \\
\hline Subtotal & 0,666 & & 2,198 \\
\hline \multicolumn{4}{|l|}{ Ancaman (Threat) } \\
\hline 1. Jumlah petani bawang merah tidak banyak & 0,091 & 3,500 & 0,319 \\
\hline 2. Harga jual produksi berfluktuasi & 0,093 & 3,575 & 0,333 \\
\hline 3. Adanya serangan hama dan penyakit & 0,061 & 2,350 & 0,144 \\
\hline 4. Perubahan iklim dan cuaca & 0,089 & 3,400 & 0,301 \\
\hline Subtotal & 0,334 & 12,825 & 1,097 \\
\hline Total & 1,000 & & 3,295 \\
\hline $\begin{array}{l}\text { Berdasarkan Tabel } 4 \text { terlihat bahwa } \\
\text { faktor eksternal yang memiliki peluang } \\
\text { terbesar adalah Kabupaten Kampar sebagai } \\
\text { sentra penanaman bawang merah. Peluang ini } \\
\text { harus mendapat perhatian dari pemerintah dan }\end{array}$ & \multicolumn{3}{|c|}{$\begin{array}{l}\text { pelaku usahatani lainnya untuk menjaga } \\
\text { stabilitas dan kontinuitas ketersediaan bawang } \\
\text { merah khususnya di Kabupaten Kampar dan } \\
\text { seluruh Kabupaten/Kota di Propinsi Riau, } \\
\text { sekaligus mampu menjadi pemasok bawang }\end{array}$} \\
\hline
\end{tabular}


merah daerah lain di seluruh Indonesia. Sementara ancaman terbesar adalah harga jual produksi yang berfluktuasi yang berdampak pada peningkatan pendapatan petani. Petani sebagai pelaku usahatani tidak memiliki kemampuan untuk menentukan harga. Perlu perhatian dari pemerintah terhadap kebijakan harga terlebih lagi jika terjadi penurunan harga yang sangat drastis. Nilai rata-rata matriks EFE yaitu 2,50 mengindikasikan bahwa petani mampu merespon dengan baik segala peluang yang mungkin diraih meskipun terdapat beberapa ancaman yang harus dihindari.

\section{Kekuatan}

1. Petani berpengalaman dalam usahatani

Khusus untuk bawang merah petani telah mengusahakan lebih kurang lima tahun, sementara tanaman lainnya seperti padi sawah dan jagung telah lebih dahulu diusahakan. Pada awal penanaman pemerintah mendatangkan langsung petani dari Brebes yang selanjutnya petani ini menurunkan ilmunya kepada petani lain. Hal ini merupakan kekuatan bagi petani karena telah memahami teknik dalam berusahatani.

2. Banyak menggunakan tenaga kerja dalam keluarga

Hampir semua petani menggunakan tenaga kerja dari dalam keluarga. Hal ini disebabkan oleh keterbatasan modal petani untuk memberi penerimaan jika menggunakan tenaga kerja dari luar. Kondisi inimerupakan kekuatan petani karena petani memahami dan mengenal setiap orang yang membantu usahataninya

3. Tergabung dalam kelompok tani aktif Petani tergabung pada dua kelompok tani yang aktif yang secara bersama-sama melakukan usahatani bawang merah pada satu hamparan yang sama (luas lahan 0,75 ha). Keuntungannya adalah segala informasi dan kaitannya pada kegiatan usahatani dilakukan bersama dibantu oleh penyuluh

4. Manajemen dalam usahatani cukup baik Salah satunya adalah dalam hal mengatur waktu tanam antara bawang merah dan padi sawah, dimana padi sawah mereka membutuhkan waktu tiga bulan untuk panen sementara bawang merah membutuhkan waktu dua bulan hingga panen. Menanam padi sawah didahulukan dan selang satu bulan tanam barulah bawang merah yang ditanam. Sehingga kedua tanaman tersebut akan panen pada waktu yang bersamaan. Alasan lain adalah agar pemakaian sarana produksi dapat digunakan bersama-sama

5. Penggunaan bibit unggul

Bibit yang digunakan petani merupakan bibit unggul jenis Brebes Bima yang didatangkan langsung dari Brebes Jawa Tengah. Penggunaan bibit sebanyak 200$250 \mathrm{~kg}$ untuk 0,75 ha atau sekitar 2.500 $\mathrm{m}^{2}$, dengan harga $\mathrm{Rp} 25.000 / \mathrm{kg}$ dan kesemua bibit tersebut langsung ditanam. Melalui penggunaan bibit unggul maka petani yakin bahwa hasil produksi memuliki mutu yang baik

6. Pupuk cukup tersedia

Pupuk yang digunakan terdiri atas pupuk kandang dan pupuk kimia yang termasuk kategori pupuk nonsubsidi dengan harga standar. Pupuk-pupuk tersebut tersedia dan dapat dibeli di kios-kios sarana produksi terdekat sehingga memudahkan bagi petani

7. Sistem pengairan yang baik

Berasal dari bendungan primer aliran Sungai Paku, dimana sistem pengairan yang digunakan petani tergolong semi teknis. Terdapat mesin mengungkit air pada sebuah parit besar yang nantinya dapat disambung menggunakan pipa untuk dialirkan ke lahan penanaman bawang merah. Petani tidak perlu takut kekurangan air disaat musim kering karena aliran air tidak pernah surut.

8. Teknik budidaya sesuai rekomendasi ahli Teknik dalam setiap tahapan budidaya bawang merah umumnya dilakukan petani sudah sesuai dengan rekomendasi ahli atau adanya kesesuian dengan prosedur yang berlaku secara standar. Artinya petani mempunyai keyakinan telah melakukan proses budidaya yang benar

\section{Kelemahan}

1. Usahatani masih berskala kecil

Hal ini merupakan salah satu kelemahan yang dominan dialami petani. Luas lahan yang dimiliki umumnya sempit atau seringkali berbagi dengan lahan tanaman lain, keterbatasan jumlah modal dan jumlah tenaga kerja, sehingga berkaitan erat dengan jumlah pendapatan yang diterima

2. Sarana transportasi masih sederhana Transportasi yang digunakan petani untuk penyediaan sarana produksi dan 
mengangkut hasil panen masih sederhana, yakni sebagian besar petani hanya menggunakan sepeda motor. Kondisi ini akan menjadi sulit jika kuantitas angkutan melebihi kemampuan angkut armada yang dimiliki

3. Belum ada lembaga yang menjamin permodalan

Kondisi ini berkaitan dengan jumlah kepemilikan modal petani yang terbatas. Tidak ada lembaga keuangan yang memberikan penawaran pinjaman sehingga petani sulit untuk membagi modalnya pada berbagai kebutuhan, baik untuk usahatani maupun kebutuhan nonusahatani

4. Fasilitas kerja umumnya manual

Fasilitas kerja yang digunakan umumnya sama dengan fasilitas usahatani lainnya yang tergolong sederhana. Kelemahannya adalah penggunaan alat manual membutuhkan jumlah tenaga kerja yang lebih banyak dibandingkan jika fasilitasnya semi mekanis atau modern.

Tabel 5. Matriks IFE (Internal Factor Evaluation)

\begin{tabular}{|c|c|c|c|}
\hline Faktor Strategis Internal & Bobot & Rating & Nilai Tertimbang \\
\hline \multicolumn{4}{|l|}{ Kekuatan (Strenght) } \\
\hline 1. Petani berpengalaman dalam usahatani & 0,041 & 3,275 & 0,133 \\
\hline 2. Banyak menggunakan TKDK & 0,044 & 3,500 & 0,152 \\
\hline 3. Tergabung dalam kelompok tani aktif & 0,045 & 3,625 & 0,163 \\
\hline 4. Manajemen usahatani cukup baik & 0,042 & 3,350 & 0,140 \\
\hline 5. Penggunaan bibit unggul & 0,050 & 4,000 & 0,199 \\
\hline 6. Pupuk cukup tersedia & 0,038 & 3,025 & 0,114 \\
\hline 7. Sistem pengairan yang baik & 0,040 & 3,200 & 0,127 \\
\hline 8. Teknik budidaya sesuai rekomendasi & 0,043 & 3,475 & 0,150 \\
\hline Subtotal & 0,341 & & 1,179 \\
\hline \multicolumn{4}{|l|}{ Kelemahan (Weaknesses) } \\
\hline 1. Usahatani masih berskala kecil & 0,036 & 2,900 & 0,105 \\
\hline 2. $\quad$ Sarana transportasi masih sederhana & 0,044 & 3,550 & 0,157 \\
\hline 3. Belum ada lembaga yang menjamin modal & 0,037 & 2,975 & 0,110 \\
\hline 4. Fasilitas kerja manual & 0,041 & 3,325 & 0,138 \\
\hline Subtotal & 0,159 & & 0,508 \\
\hline Total & $\mathbf{1 , 0 0 0}$ & & 1,688 \\
\hline
\end{tabular}

Tabel 5 memperlihatkan kekuatan internal terbesar adalah penggunaan bibit unggul. Umumnya petani mengggunakan bibit bawang merah varietas Bima yang langsung didatangkan dari Brebes Jawa Tengah untuk menjaga kualitas hasil produksi. Petani meyakini bahwa pembeli/konsumen tentu akan memilih dan mengkonsumsi bawang merah dengan mutu yang baik. Sementara kelemahannya adalah sarana transportasi yang masih sederhana. Petani umumnya masih menggunakan sepeda motor dalam pengangkutan sarana dan hasil produksi. Ketidakmampuan petani menggunakan alat transportasi yang lebih besar (dalam hal ini mobil) berkaitan dengan keterbatasan modal usaha. Matriks IFE memiliki nilai rata-rata 2,50 mengindikasikan bahwa petani belum mampu untuk menggunakan seluruh kekuatan yang dimiliki dan meminimalkan kelemahannya. Perlu adanya perhatian dari pemerintah berkaitan dengan kemudahan bagi petani dalam memperoleh bantuan permodalan, khususnya pinjaman dengan biaya angsuran rendah dan periode pinjaman yang lebih fleksibel.

\section{Matriks IE (Internal External Matrix)}

Matriks IE atau disebut juga matriks portofolio terdiri dari dua dimensi yaitu total nilai tertimbang IFE yang ditempatkan pada sumbu $\mathrm{x}$ dan total nilai tertimbang EFE pada sumbu y. Berdasarkan hasil analisis matriks EFE diperoleh total nilai tertimbang sebesar 3,295 dan total nilai tertimbang matriks IFE adalah 1,688, yang menempatkan usahatani bawang merah berada pada sel III, seperti yang terlihat pada gambar 2. Terdapat 2 (dua) strategi terbaik yang dapat diterapkan yaitu strategi penetrasi pasar dan pengembangan produk.

Strategi penetrasi pasar dilakukan apabila pasar tidak jenuh dengan keadaan yang ada dan tingkat konsumsi meningkat secara signifikan. Hal ini dapat dilakukan dengan 
menjaga ketersediaan produk secara kontiniu, pengiriman produk ke konsumen dengan tepat waktu dan sesuai pesanan, dan menjaga kualitas produk dengan baik. Sementara strategi pengembangan produk dilakukan ketika produk berada pada siklus dewasa, perusahaan bersaing dalam industri

berteknologi cepat. Beberapa hal yang dapat dilakukan oleh petani bawang merah di Kabupaten Kampar adalah menjaga dan meningkatkan kualitas produk yang didukung dengan SOP (Standard Operational Procedure), dan stabilitas tingkat kebersihan produk.

Total Nilai Tertimbang IFE
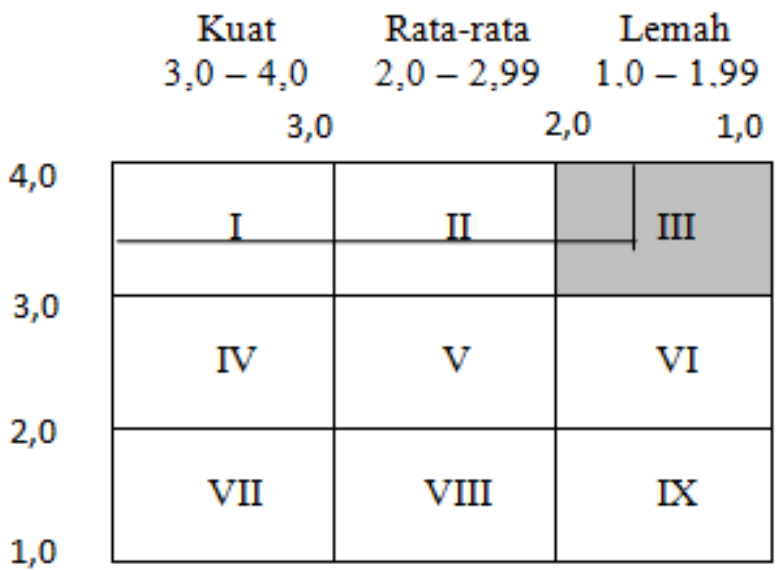

Gambar 2. Matriks Internal Eksternal (IE) Usahatani Bawang Merah

Tabel 6. Matriks SWOT Usahatani Bawang Merah di Desa Sungai Geringging

\begin{tabular}{|c|c|c|}
\hline Faktor Eksternal & \begin{tabular}{ll} 
& \multicolumn{1}{c}{ Kekuatan (Strenght) } \\
1. & Petani berpengalaman \\
2. & Banyak menggunakan TKDK \\
3. & Tergabung kelompok tani aktif \\
4. & Manajemen usahatani baik \\
5. & Penggunaan bibit unggul \\
6. & Pupuk cukup tersedia \\
7. & Sistem pengairan yang baik \\
8. & Teknik budidaya sesuai \\
& rekomendasi
\end{tabular} & 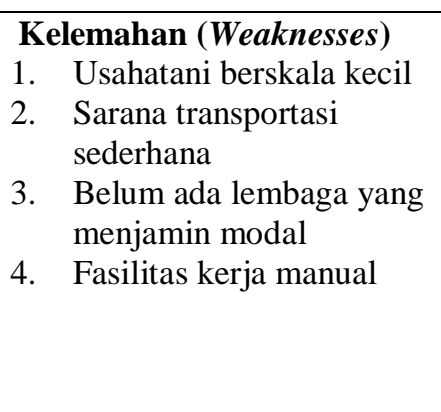 \\
\hline 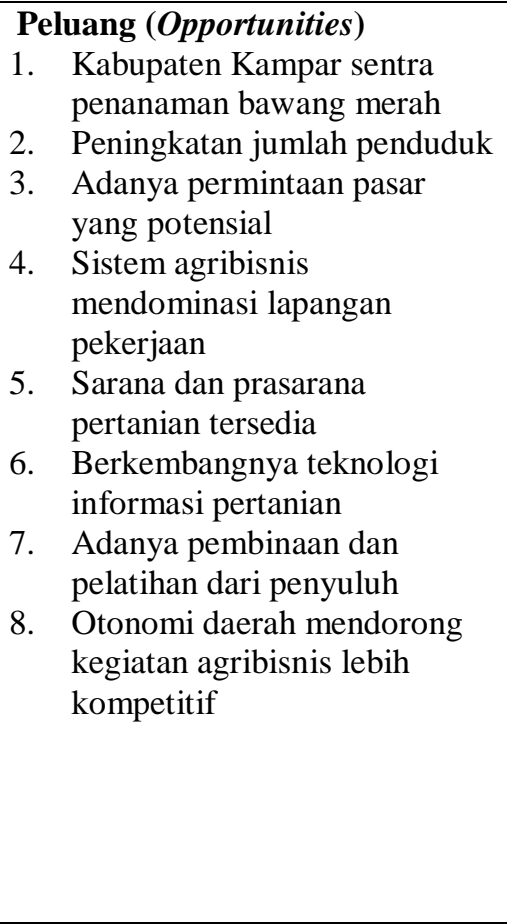 & 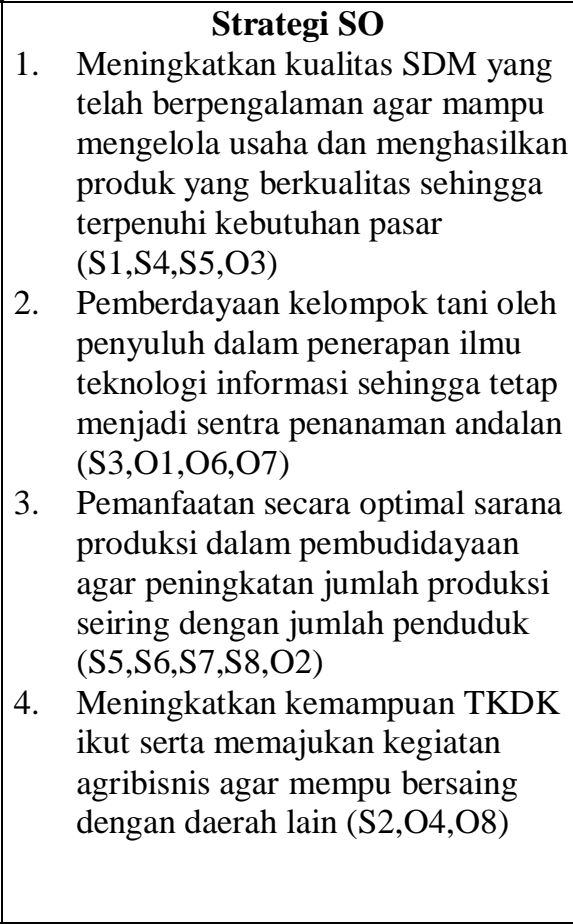 & 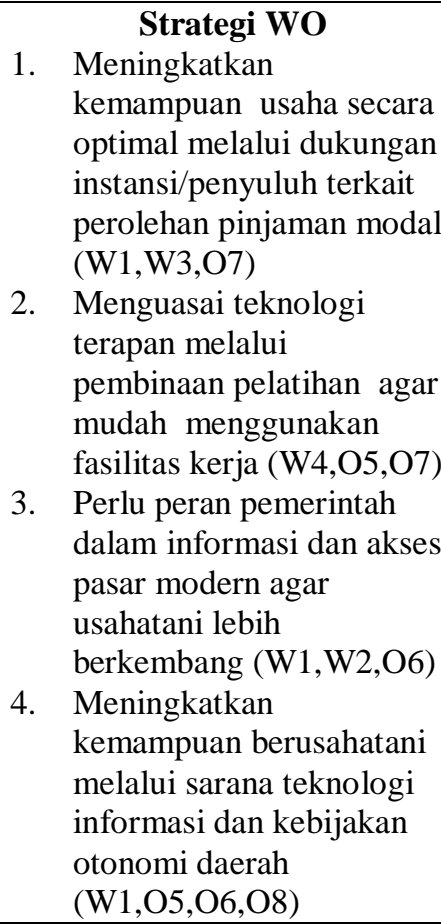 \\
\hline
\end{tabular}




\begin{tabular}{|c|c|c|}
\hline $\begin{array}{l}\text { Ancaman (Threat) } \\
\text { 1. Jumlah petani bawang merah } \\
\text { tidak banyak } \\
\text { 2. Harga jual produksi } \\
\text { berfluktuasi } \\
\text { 3. Adanya serangan hama dan } \\
\text { penyakit } \\
\text { 4. Perubahan iklim dan cuaca }\end{array}$ & $\begin{array}{l}\text { Strategi ST } \\
\text { 1. } \begin{array}{l}\text { Meningkatkan kemampuan SDM } \\
\text { dan kelompok tani mengantisipasi } \\
\text { serangan hama dan penyakit serta } \\
\text { perubahan iklim (S1,S3,T3,T4) }\end{array} \\
\text { 2. } \begin{array}{l}\text { Perlu dibentuk asosiasi petani agar } \\
\text { fluktuasi harga tidak berdampak } \\
\text { bagi produksi dan pendapatan } \\
\text { (S1,S3,S8,W2) }\end{array} \\
\text { 3. Menumbuhkan jiwa \& pengelolaan } \\
\text { usahatani yang baik agar jumlah } \\
\text { petani meningkat dan berproduksi } \\
\text { dengan harga jual yang } \\
\text { menguntungkan (S2,S4,W1,W2) } \\
\text { Mengoptimalkan penggunaan bibit, } \\
\text { pupuk, dan sarana lainnyaterhadap } \\
\text { kemungkinan perubahan iklim dan } \\
\text { hama penyakit (S5,S6,S7,T3,T4) }\end{array}$ & \begin{tabular}{ll}
\multicolumn{1}{c}{ Strategi WT } \\
1. & $\begin{array}{l}\text { Meningkatkan informasi } \\
\text { pasar dan kemudahan } \\
\text { memperoleh modal untuk } \\
\text { mengimbangi harga jual } \\
\text { yang berfluktuasi } \\
\text { (W1,W3,T2) }\end{array}$ \\
2. & $\begin{array}{l}\text { Kerjasama dinas terkait } \\
\text { dan stakeholder dalam } \\
\text { pengenalan alsintan }\end{array}$ \\
modern (W1,W2,T1) \\
3. Pengoptimalan inovasi \\
baru sehingga tersedia \\
bibit unggul yang tahan \\
terhadap hama dan \\
penyakit (W1,W4,T3,T4) \\
Mengintensifkan budidaya \\
dan perawatan tanaman \\
(W1,T1,T3,T4)
\end{tabular} \\
\hline
\end{tabular}

\section{KESIMPULAN}

1. Peluang bagi usahatani bawang merah adalah Kabupaten Kampar merupakan sentra penanaman bawang merah namun harus mampu meminimalisir harga jual produksi yang berfluktuasi. Sedangkan faktor internal yang menjadi kekuatan usahatani adalah penggunaan bibit unggul dan kelemahannya adalah sarana transportasi masih sederhana. Melalui matriks IE usahatani bawang merah berada pada sel III sehingga dapat menjalankan strategi penetrasi pasar dan pengembangan produk

2. Melalui analisis SWOT diketahui bahwa usahatani dapat menjalankan strategi WO (Weaknesses-Opportunities) diantaranya meningkatkan kemampuan usaha secara optimal melalui dukungan instansi/penyuluh terkait perolehan pinjaman modal, menguasai teknologi terapan melalui pembinaan pelatihan agar mudah menggunakan fasilitas kerja, perlu peran pemerintah dalam informasi dan akses pasar modern agar usahatani lebih berkembang, meningkatkan kemampuan berusahatani melalui sarana teknologi informasi dan kebijakan otonomi daerah

\section{DAFTAR PUSTAKA}

David, F.R. 2009. Manajemen Strategi. Salemba Empat, Jakarta

Dinas Pertanian Tanaman Pangan dan Hortikultura Kabupaten Kampar. 2014.
Jumlah Produksi Bawang Merah di Kabupaten Kampar, Bangkinang

Erny. 2010. Strategi Pengembangan Usahatani Bawang Merah Lokal di Kabupaten

Donggala. Tesis S2 Ekonomi Pertanian Universitas Gadjah Mada, Yogyakarta

Hasibuan. 2002. Manajemen Sumber Daya Manusia: Dasar dan Kunci Keberhasilan. Gunung Agung, Jakarta

Hurriyati, Ratih. 2005. Bauran Pemasaran dan Loyalitas Konsumen. Alfabeta, Bandung

James, G. 2004. Perilaku Organisasi. Rineka Cipta, Jakarta

Kuncoro, M. 2003. Metode Riset untuk Bisnis dan Ekonomi. Erlangga, Jakarta

Munandar, A, Sunyoto. 2001. Psikologi Industri dan Organisasi. Universitas Indonesia, Jakart

Rangkuti, F. 2003. Analisis SWOT Teknik Membedah Kasus Bisnis. Reorientasi Konsep Perencanaan Strategis untuk Menghadapi Abad 21. Gramedia Pustaka Utama, Jakarta

Rauf R.A, S. Darman, A. Andriana. 2015. Pengembangan Usahatani Bawang merah Varietas Lembah Palu. Jurnal Agriekonomika, 4 (2): 247-259

Samadi, B dan B. Cahyono. 2005. Intensifikasi Budidaya Bawang Merah. Kanisius, Yogyakarta

Sedarmayanti. 2009. Sumber Daya Manusia dan Produktivitas. Mandar Maju, Bandung

Simamora, H. 2004. Manajemen Sumber Daya Manusia. STIE YKPN, Yogyakarta 
Sugiyanto. 2013. Strategi Pengembangan Tanaman Bawang Merah Berbasis Agribisnis di Desa Duwel Kecamatan Kedungasem Kabupaten Bojonegoro. Universitas Bojonegoro, Jawa Tengah

Sulaiman. 2002. Jalan Pintas Menguasai SPSS. Andi Offset, Yogyakarta

Suparman. 2010. Bercocok Tanam Bawang Merah. Azka Press, JakartaWibowo S. 2007. Budidaya Bawang Merah. Penebar Swadaya, Jakarta 